OPEN ACCESS

Edited by: Osman Titrek,

Sakarya University, Turkey

Reviewed by:

Ahmet Güneyli,

European University of Lefke, Turkey

Aysegul Ayyildiz,

Hakkari University, Turkey

*Correspondence:

Semih Çayak

semihcayak@gmail.com

Specialty section:

This article was submitted to

Organizational Psychology,

a section of the journal

Frontiers in Psychology

Received: 11 September 2021 Accepted: 09 December 2021

Published: 23 December 2021

Citation:

Çayak S and Eskici M (2021) The

Mediating Role of Emotional

Intelligence in the Relationship

Between School Principals' Sustainable Leadership Behaviors and Diversity Management Skills.

Front. Psychol. 12:774388

doi: 10.3389/fpsyg.2021.774388

\section{The Mediating Role of Emotional Intelligence in the Relationship Between School Principals' Sustainable Leadership Behaviors and Diversity Management Skills}

\author{
Semih Çayak ${ }^{1 \star}$ and Menekşe Eskici² \\ ${ }^{1}$ Republic of Turkey Ministry of National Education, Istanbul, Turkey, ${ }^{2}$ Curriculum and Instruction Program, Department \\ of Educational Sciences, Faculty of Science and Literature, Kırklareli University, Krrklareli, Turkey
}

The purpose of this research is to examine the mediating role of emotional intelligence in the relationship between school principals' sustainable leadership behaviors and their diversity management skills. For this purpose, this research, which was designed in the relational survey model, was carried out on teachers. The data of the study were collected using the "Sustainable Leadership Scale," "Diversity Management Scale," and "Emotional Intelligence Scale." Descriptive statistics, Pearson productmoment correlation coefficient, $t$-test, one-way ANOVA analyses and structural equation model were used in the analysis of the data. As a result of the research, it was found that the school principals' sustainable leadership behavior levels, their ability to manage differences and their emotional intelligence levels were high according to teacher perceptions. According to the correlation analysis, it was found that there is a positive and significant relationship between sustainable leadership, diversity management, and emotional intelligence. In addition, path analyses to examine the mediator variable effect revealed that emotional intelligence has a full mediating role in the relationship between school principals' sustainable leadership behaviors and their diversity management skills. In addition to the research, it was also examined whether teachers perceptions of school principals on sustainable leadership behaviors, diversity management skills, and emotional intelligence levels differ significantly according to teachers' gender, professional seniority, educational status and the level of education they work in. In addition to this, they have shown that they need to use their emotional intelligence effectively.

Keywords: sustainable leadership, emotional intelligence, diversity management, school principals, mediating role

\section{INTRODUCTION}

Changes in social, political, technological and economic life and globalization affect the philosophies, cultures and strategies of organizations. This change leads to great differentiations especially in the workforce profile (Clegg and Carter, 2009; Almeida and Chase-Dunn, 2018). In this process, the management of human resources, which has become the most basic element of service and production in organizations has gained more importance, so new approaches to management 
styles and human relations have begun to be needed (Teece, 2018), because every employee in organizations has different characteristics and values. For this reason, knowing the reflections of differences such as demographic and individual characteristics, personality, socio-cultural values, ability-skills and perception, personal conceptualization characteristics, emotional adaptation characteristics, age-experience, gender on the management, individual and organizational benefits and drawbacks of the employees in the organizations will make it possible to evaluate the differences in managerial policies and practices in line with the goals of the organization. Thus, the potential power of each individual making up the organization will be utilized at the maximum level (Campbell, 2000; Lysova et al., 2019; Yahyayeva, 2020).

The concept of managing diversity together gains importance in terms of establishing a better functioning global management system as well as better management of organizations (Pless and Maak, 2004). New administrative structures will rise on the basis of democracy and equality based on respect for the differences. If diversities are not seen as a problem and they can participate in rich management systems brought by diversity, the importance of developing knowledge and skills on the diversity management will increase. At this point, organizational managers have great responsibilities (Trittin and Schoeneborn, 2017). Organizational managers will be able to both provide a competitive advantage against other organizations and maintain their organization for a long time if they can see the diversities of organizational members as a wealth with their leadership behaviors and use them effectively in the context of realizing organizational goals (Coleman, 2012). It is thought that this may be closely related so to the sustainable leadership behaviors of organizational managers (Urbancová et al., 2020; Zeltina, 2020). As a matter of fact, the sustainable leadership approach, which is one of the leadership types on which researches are frequently conducted, is based on an understanding that supports and protects diversities in organizations and argues that a sustainable organizational system can only be realized in this way. Leaders are people who have the power to control, influence and direct the emotions, thoughts and most importantly the behaviors of individuals. From the point of view of educational organizations, school principals will be described as successful leaders when they have the ability to recognize their own personal feelings, be aware of their limits, understand and attach importance to the feelings of others, control stress and anger, be empathetic, and be successful in human relations (Ergin, 2008; Ismayllov, 2019). This seems to be closely related to the emotional intelligence levels of leaders.

\section{THEORETICAL BACKGROUND}

\section{Sustainable Leadership}

People live in groups and need a leader to manage the group they belong to and lead them to their goals. This leader, who is at the head of the group, unites the individuals in the group around a goal and increases their courage and energy. In order to achieve this, leaders are expected to have certain characteristics.
Sustainable leadership which aims to enable organizations to build their current situation toward a successful future rather than focusing only on long-term and financial success (Hargreaves, 2007), requires encouraging systematic innovation and providing quality products, services and solutions (Avery and Bergsteiner, 2011). Davies (2007), on the other hand, describes sustainable leadership as "one of the key factors" that underlines the long-term development of the school, and states that sustainable leadership fosters a leadership culture based on the moral purpose of the school, which in turn ensures success for the benefit of all. In this context, passion for continuous improvement, balancing between past tradition and innovations, thinking about the process, encouraging the participation of all members of the organization, developing strategic measures to ensure success and establishing school-society partnership should be characterized by such features (Iliško and Badyanova, 2014).

Sustainable leadership has some benefits for organizations. Some of these benefits, often highlighted in the literature are: Sustainable leadership practices are estimated to improve long-term organizational performance to varying degrees (Suriyankietkaew and Avery, 2016). Sustainable leadership can respond quickly and flexibly to all stakeholders (Avery and Bergsteiner, 2011) and thus, overall stakeholder satisfaction of organizations that adopt sustainable leadership practices increases (Suriyankietkaew and Avery, 2014). Sustainable characteristics of those who manage educational environments also require them to be sensitive to the characteristics of the individuals they work with.

\section{Diversity Management}

The management of diversity is based on accepting individual differences in organizations as they are, not making any discrimination against any person or group, and evaluating the diversities of people in various dimensions in line with individual and organizational purposes. Diversity management is a comprehensive management philosophy that aims to reveal the potentials of all employees in the organization and to evaluate and benefit from these diversities in practice (Jabbour et al., 2011). This philosophy envisages that individuals and groups in the organization protect their own characteristics and that it affects the organization as well as the individual, and that the whole of common values in the organization is formed. Thus, it aims to reveal all the talents of the employees and to develop them in a way that contributes to the goals of the organization (Shen et al., 2009; Urbancová et al., 2016).

As educational organizations, schools contain students and teachers with many different characteristics (Bryan, 2010). Therefore, the diversity management skills of school principals will be of great importance in the effective and efficient management of schools, whose inputs and outputs are recognized, and which contain individuals with so many different characteristics (Young et al., 2010). Thus, it will be possible to reveal all the talents of the employees in the school organization and to develop them in a way that will contribute to the goals of the organization. The process of managing diversities is closely related to the management of emotions. The higher an 
individual's emotional intelligence, the higher his or her ability to manage their emotions and thus diversities.

\section{Emotional Intelligence}

Salovey and Mayer (1990), influenced by Gardner's (1983) multiple intelligence types, discussed that the individual's ability to perceive and regulate his own and other individuals' emotions differ and developed the first emotional intelligence model (Gürdere, 2015). Titrek (2013) defined emotional intelligence as understanding the feelings, emotions and thoughts of ourselves and those we communicate with, empathizing with others, managing our emotions by leaving aside fears and thus getting optimum efficiency from our emotions. Goleman (2016), one of the leading researchers in the field of emotional intelligence and the most widely accepted and detailed definition of emotional intelligence in the literature, defines emotional intelligence as; the ability to mobilize oneself, to control impulses, to regulate mood, not to let troubles interfere with thinking, to put oneself in someone else's shoes, and to hope.

Employees with high emotional intelligence have personality traits that recognize and control their emotions, as well as understand and manage the emotions of others (Dulewicz and Higgs, 2000). For this reason, emotional intelligence gives the individual many advantages in business life and helps the organization to create positive emotions instead of negative emotions and to show more positive behaviors to employees (Gül et al., 2014). In this context, emotional intelligence has a special place in schools as educational organizations, as in other organizations. Because school principals, who know themselves well and can direct their emotions, give more positive reactions to the behaviors of teachers and students. They know what they feel and what emotions they experience, and they can direct the emotions and thoughts of school members in this direction in order to create a better school environment (Weisinger, 1998; Danilov and Mihailova, 2020).

\section{CONCEPTUAL FRAMEWORK}

\section{The Relationship Between Sustainable Leadership, Diversity Management, and Emotional Intelligence}

Within the scope of the research, studies on emotional intelligence, sustainable leadership and the diversity management were examined. It has been observed that these variables have been studied on different samples such as educational institutions and other businesses. However, no research has been found in the literature in which these three variables are used together, both on educational organizations and on other organizations. There are explanations in the literature that sustainable leadership positively supports the management of diversity in organizations (Morrison and Milliken, 2000; Pinder and Harlos, 2001). In addition, one of the principles of sustainable leadership stated by Hargreaves and Fink (2006) is diversity. The principle of diversity refers to allowing all voices to be heard within the organization. On the other hand, Lambert (2011) who conducts research on sustainable leadership, examined the principles of sustainable leadership in two categories as inclusiveness and developmentalism. Among these principles, inclusiveness states that sustainable leadership should respect and support diversities within the organization. Similarly, Lambert (2011) examines the elements of sustainable leadership under six headings: "creating personnel capacity, strategic distribution, unification, generating long-term goals from short-term goals, diversity and protection," and emphasizes the importance of diversity in sustainable leadership. Therefore, it can be considered as an expected situation that sustainable leadership supports the management of diversity positively.

Emotional elements lie on the basis of the leader's being understood by the organization. For this reason, it has become necessary for a leader to have emotional intelligence skills to be effective and successful. Goleman (2017) stated that the reason why emotional intelligence is very important in the success of the leader is that this dimension of leadership, which is related to emotions, determines the course of what the leader does. In this respect, although organizational managers emphasize that they have effective sustainable leadership behaviors, some studies have shown that emotional intelligence levels are also effective in realizing these behaviors. E.g., Ulrich and Smallwood (2013), who classified the principles that guide sustainable leadership as "simplicity," "time," "accountability," "resources," "tracking," "melioration," and "emotion," and drew attention to the importance of "emotion" in sustainable leadership in their last principle. According to Ulrich and Smallwood (2013), sustainable change is also a matter of the heart and needs a strong emotional person rather than an intellectual person.

Based on the information presented above, it is thought that there may be a significant relationship between sustainable leadership and the management of diversity in organizations. In addition, in organizations where people with different characteristics come together, it is possible that the emotional intelligence levels of leaders can play a mediating role between these two variables. In the literature, emotional intelligence may be associated with both sustainable leadership (BadriHarun et al., 2016; Augusty and Mathew, 2020) and diversity management (Gardenswartz et al., 2010; Kaufmann and Wagner, 2017). However, no study was found in the literature in which these three variables were used together. Based on these considerations, in this study, the mediating role of emotional intelligence in the relationship between sustainable leadership and diversity management was examined. In addition, it was also examined whether the opinions of the participants regarding these three variables showed statistically significant differences according to their demographic characteristics. The research was carried out with teachers working in schools, which are the organizations where human relations are most intense.

\section{Purpose of the Research}

The aim of this research is to examine the relationship between school principals' sustainable leadership behaviors, diversity management skills and emotional intelligence levels according to teachers' opinions. In this direction, answers to the following questions were sought in the study. 
(1) What are the teachers' perceptions of the school principals' sustainable leadership behaviors, diversity management skills and emotional intelligence levels?

(2) Do teachers' perceptions of school principals' sustainable leadership behaviors, diversity management skills and emotional intelligence levels show a statistically significant difference according to teachers' demographic characteristics?

(3) According to teachers' perceptions, is there a significant relationship between school principals' sustainable leadership behaviors, diversity management skills and emotional intelligence levels?

(4) According to teachers' perceptions, does emotional intelligence have a mediating effect on the relationship between school principals' sustainable leadership behaviors and their diversity management skills?

\section{MATERIALS AND METHODS}

\section{Research Model}

This research, which examines the relationships between school principals' sustainable leadership behaviors, diversity management skills, and emotional intelligence levels according to teachers' perceptions, was designed in the relational survey model, one of the quantitative research methods. In this study, the mediating role of emotional intelligence in the relationship between sustainable leadership and diversity management was tested.

\section{Population and Sample}

The population of the research consists of 11,025 teachers working in Pendik $(7,368)$ and Kartal $(3,657)$ districts of Istanbul in the 2020-2021 academic year. Simple random sampling method was used to determine the sample. It is considered sufficient for the sample that can represent the population, which is between 10,000 and 15,000 with a $5 \%$ error rate in the sampling determination table, to be in the range of 370375 (Krejcie and Morgan, 1970). Based on this information, the research was conducted with 402 teachers. Table 1 shows the distribution of teachers participating in the research according to their demographic characteristics.

According to Table 1, 224 of the 402 teachers were female (56\%) and 178 were male (44\%). In addition, 115 (29\%) of the teachers have 0-5 years seniority, 81 (20\%) 6-10 years of seniority, 82 (20\%) 11-15 years of seniority, 75 (19\%) 16-20 years of seniority, and $49(12 \%)$ have 21 years or more of professional seniority. It was observed that $340(85 \%)$ of the teachers were at the undergraduate level and $62(15 \%)$ were at the graduate level. When the educational levels of the teachers were examined, it was observed that 155 (39\%) teachers worked in primary schools, $147(36 \%)$ teachers in secondary schools, and 100 (25\%) teachers in high schools.

\section{Data Collection Process and Tools}

In the research; Sustainable Leadership Scale developed by Çayak and Çetin (2018); Diversity Management Scale developed by
Balay and Sağlam (2004), and Emotional Intelligence Scale developed by Titrek (2005) were used. The psychometric properties of data collection tools are presented below.

\section{Sustainable Leadership Scale}

The Sustainable Leadership Scale, which was developed by Çayak and Çetin (2018) and aims to measure the sustainable leadership behavior levels of school principals according to a teacher perception, is a five-point Likert type scale consisting of 4 sub-dimensions and 36 items. Thirty-six items with factor loadings between 0.55 and 0.79 explain $66.71 \%$ of the total variance. The goodness of fit values obtained as a result of the confirmatory factor analysis regarding the four-factor structure of the scale are as follows: $\mathrm{x}^{2} / \mathrm{df}=3.55$; TLI $=0.91$; CFI $=0.92$, and RMSEA $=0.06$. The Cronbach's Alpha internal consistency coefficients calculated for the sub-dimensions and it was found to be 0.97 for the Administrative Sustainability sub-dimension; 0.92 for the Economic Sustainability sub-dimension; 0.85 for the Cultural Sustainability sub-dimension; 0.87 for the Social Sustainability sub-dimension; and 0.98 for the overall scale.

\section{Diversity Management Scale}

The Diversity Management Scale, developed by Balay and Sağlam (2004), is a five-point Likert-type scale consisting of three subdimensions and 28 items. The variance rate explained by the sub-dimensions of the diversity management scale was $11.4 \%$ for the first sub-dimension, "Individual Attitudes and Behaviors"; $15.7 \%$ for the second sub-dimension, "Organizational Values and Norms"; and 31\% for the third sub-dimension, "Managerial Practices and Policies." The variance value of the Diversity Management Scale explained as a single factor is $41.7 \%$. The Cronbach's Alpha reliability coefficient of the scale was calculated as 0.77 for the first factor, 0.83 for the second factor and 0.95 for the third factor. In the study, the general reliability of the scale was calculated as 0.85 . It can be said that as the scores obtained from the dimensions of the scale increase, teachers' perceptions of the diversity management related to that dimension increase in a positive way.

\section{Emotional Intelligence Scale}

Donaldson-Feilder and Bond (2004) state that the use of selffilled (based on self-assessment) scales in the evaluation process of emotional intelligence can be potentially misleading. For this reason, it is important that the results of the studies on school administrators are more objective and that the scales are applied to other people who observe them, not to the people to be evaluated, in order to obtain more reliable results. Based on this information, the Emotional Intelligence Scale developed by Titrek (2005) was used in the research. The emotional intelligence scale is a five-point Likert-type scale consisting of five sub-dimensions and 72 items. The rate of variance explained by the sub-dimensions of the Emotional Intelligence Scale was $52 \%$ for the first sub-dimension "SelfAwareness (Awareness of Your Emotions)," 56\% for the second sub-dimension "Regulating and Managing Emotions," and 70\% for the third sub-dimension, "Motivation of Emotions," 52\% for the fourth sub-dimension "Empathy" and 62\% for the fifth 
sub-dimension "Social Skills." The Cronbach's Alpha reliability coefficient of the scale was 0.77 for the "Self-Awareness" subdimension, 0.81 for the "Regulating and Managing Emotions" sub-dimension, 0.83 for the "Motivation of Emotions" subdimension, 0.74 for the "Empathy" sub-dimension and 0.89 for the "Social Skills" sub-dimension. In the study, the general reliability of the scale was calculated as 0.96 .

\section{Personal Information Form}

In the personal information form prepared by the researchers, questions about the gender of the participants, their professional seniority, their educational status, and their educational levels were included.

\section{Procedures and Data Analysis}

The scale links prepared through Google forms were sent to the teachers who wanted to participate in the research voluntarily by the school administration. Data collected from 402 teachers were analyzed using the SPSS 22.0 program. In the analysis of the data obtained within the scope of the research, descriptive statistics related to the variables were calculated and the relations between the variables were determined using the Pearson product-moment correlation coefficient. Afterward, mediation analyses were made using the structural equation model and path analysis in line with the model proposed by Baron and Kenny (1986). Statistical programs (SPSS and AMOS) were used in the analysis of the data collected within the scope of the research. Before starting the analysis firstly, whether or not the data set had unidirectional and multidirectional normality assumption was analyzed. For this purpose, the skewness and kurtosis values of the data set and the Q-Q graphs were examined. Administrative sustainability $(-0.01$ to -0.08$)$, economic sustainability ( -0.21 to 0.09 ), cultural sustainability ( 0.31 to -0.10 ), social sustainability ( 0.44 to 0.07 ), sustainable leadership overall average $(-0.01$ to -0.24$)$, individual attitudes and behaviors $(0.14$ to -0.40$)$, organizational values and norms $(-0.26$ to 0.29$)$, managerial practices and policies $(-0.16$ to $0.06)$, diversity management overall average $(-0.08$ to 0.15$)$, self-awareness $(0.11$ to -0.15$)$, managing emotions $(-0.25$ to $-0.50)$, emotional motivation ( -0.28 to 0.51$)$, empathy $(-0.10$ to 0.14 ), social skills ( -0.11 to 0.14 ), and emotional intelligence overall average ( 0.10 to 0.06$)$ scores were within the normal distribution limits. George and Mallery (2003) state that when the skewness and kurtosis coefficients are in the range of \pm 2 , the data show normal distribution. In addition, it has been observed that the expected and actual values of the data are distributed close to a line with a slope of 45 degrees in the created Q-Q charts. Therefore, this showed that the distribution of the data would be considered normal (Can, 2014). Since multivariate analyses were used in the study, it was also examined whether there was a multicollinearity problem between the variables. In this, the correlation values between the variables were examined. The correlation between the predictor variables above 0.80 indicates that there may be a multicollinearity problem, while the correlation above 0.90 indicates that there may be an important multicollinearity problem (Büyüköztürk, 2011). Based on this information, as seen in Table 2, there is
TABLE 1 | Data on demographic characteristics of the participants.

\begin{tabular}{lccc}
\hline $\begin{array}{l}\text { Demographic } \\
\text { variable }\end{array}$ & Groups & Frequency $(\boldsymbol{n})$ & Percentage (\%) \\
\hline Gender & Female & 224 & 56 \\
& Male & 178 & 44 \\
& Total & 402 & 100 \\
Professional & $0-5$ years & 115 & 29 \\
seniority & & & \\
& 6-10 years & 81 & 20 \\
& $11-15$ years & 82 & 20 \\
& 16-20 years & 75 & 19 \\
& 21 years or more & 49 & 12 \\
Graduation & Total & 402 & 100 \\
& Undergraduate degree & 340 & 85 \\
& Graduate degree & 62 & 15 \\
Level of education & Total & 402 & 100 \\
to work & Primary school & 155 & 39 \\
& & & \\
& Secondary school & 147 & 36 \\
& High school & 100 & 25 \\
& Total & 402 & 100 \\
\hline
\end{tabular}

TABLE 2 | Descriptive statistics and correlation analysis of variables.

\begin{tabular}{lccc}
\hline & $\mathbf{1}$ & $\mathbf{2}$ & $\mathbf{3}$ \\
\hline 1. Sustainable Leadership & 1 & & \\
2. Emotional Intelligence & $0.68^{\star}$ & 1 & \\
3. Diversity Management & $0.50^{\star}$ & $0.78^{\star}$ & 1 \\
Mean & 3.90 & 3.95 & 3.87 \\
Standard Deviation & 0.32 & 0.33 & 0.36 \\
Skewness & -0.01 & 0.10 & 0.00 \\
Kurtosis & -0.24 & 0.06 & -0.15 \\
\hline
\end{tabular}

* $p<0.01$.

no multicollinearity problem between sub-dimensions. In the analyses, the significance of the difference between the means was tested at the 0.05 level. In the interpretation of arithmetic averages, the range of 1.00-1.79 was evaluated as "very low," the range of 1.80-2.59 as "low," the range of 2.60-3.39 as "medium," the range of 3.40-4.19 as "high," and the range of 4.20-5.00 as "very high." In addition, in the interpretation of the correlation analysis, the range of $0.00-0.30$ was accepted as "low," the range of $0.31-0.70$ as "medium," and the range of $0.71-1.00$ as "high" level (Büyüköztürk, 2011). The study’s first question was investigated by the arithmetic mean, the second question by Pearson productmoment correlation analysis, the third question by $t$-test and one-way analysis of variance (ANOVA), and the fourth question by structural equation modeling (SEM).

\section{FINDINGS}

In the study, school principals' sustainable leadership behaviors, their ability to manage differences and their emotional intelligence levels were examined and it was examined whether these showed significant differences according to 
some demographic variables. In addition, the results of the correlation analysis between the variables were given, and then the structural equation model regarding the mediating role of emotional intelligence levels in the relationship between school principals' sustainable leadership behaviors and their ability to manage differences was tested.

The relationships between the arithmetic mean, standard deviation and skewness-kurtosis values of the scores obtained from the scales used in the research and the scale scores are presented in Table 2.

When the descriptive statistics in Table 2 are examined, it is seen that the teachers' perceptions of sustainable leadership $(\bar{X}=3.90)$, their ability to manage differences $(\bar{X}=3.87)$ and their emotional intelligence perception levels $(\overline{\mathrm{X}}=3.95)$ are relatively high. In addition, when the skewness and kurtosis values of the variables discussed in the study are examined, it is seen that the distribution exhibits a normal distribution. Looking at the correlation coefficients between the variables in Table 1, there is a positive, moderately significant relationship between sustainable leadership and diversity management $(r=0.50$; $p<0.001)$. Likewise, there is a positive, moderately significant relationship between sustainable leadership and emotional intelligence $(r=0.68 ; p<0.001)$. In addition, a positive and highly significant relationship was found between emotional intelligence and diversity management $(r=0.78 ; p<0.001)$.

An independent group $t$-test was conducted to determine whether the sustainable leadership scale, emotional intelligence scale and diversity management scale scores of the teachers constituting the sample group showed a significant difference according to the gender variable.

As can be seen in Table 3, as a result of the independent groups $t$-test, sustainable leadership $(t=-0.34 ; p>0.05)$, emotional intelligence $(t=-1.60 ; p>0.05)$, and diversity management $(t=-0.59 ; p>0.05)$ scores, the difference between the arithmetic means of the groups was not significant.

A one-way ANOVA was conducted in order to determine whether the scores of the sustainable leadership scale, the emotional intelligence scale and the diversity management scale of the teachers constituting the sample group show a significant difference according to the professional seniority variable.

As seen in Table 4, as a result of the one-way ANOVA, the difference between the arithmetic averages of the groups for the sustainable leadership score $(F=1.708 ; p>0.05)$ according to the variable of professional seniority was not found significant. However, the difference between the arithmetic mean scores of the groups for emotional intelligence $(F=2.859$; $p<0.05)$ and diversity management $(F=4.749 ; p<0.05)$ scores according to the variable of professional seniority was found to be significant. Complementary analyses (post-hoc) were carried out in order to determine from which groups the significant difference detected for emotional intelligence and the diversity management originates. For this purpose, firstly, the homogeneity of variance was checked with Levene's analysis and it was found that the variances were not homogeneous $\left(\mathrm{L}_{F}=5.626 ; p<0.05 / \mathrm{L}_{F}=3.107 ; p<0.05\right)$. For this reason, the Dunnet $C$-test was preferred. As a result of the Dunnet $C$-test, it was found that a significant difference for the emotional intelligence scale was in favor of teachers with 6-10 years of seniority between teachers with 6-10 years of seniority and those with $0-5$ years of seniority. On the other hand, for the diversity management scale, the significant difference was found between teachers with 6-10 years of seniority and teachers with $0-5$ years of experience, and between teachers with 16-20 years of seniority and teachers with $0-5$ years of experience.

An independent group $t$-test was conducted to determine whether the sustainable leadership scale, emotional intelligence and diversity management scale scores of the teachers constituting the sample group showed a significant difference according to the variable of educational status.

As can be seen in Table 5, as a result of the independent groups $t$-test, the difference between the arithmetic averages of the groups for the sustainable leadership $(t=-1.95 ; p>0.05)$ score according to the educational status variable was not found significant. However, the difference between the arithmetic means of the groups for emotional intelligence $(t=-2.54$; $p<0.05)$ and diversity management $(t=-2.43 ; p<0.05)$ scores was found to be significant. The averages of the teachers at the graduate education level were found to be significantly higher than the averages of the teachers with the undergraduate education level.

The mediating effect of emotional intelligence on the relationship between school principals' sustainable leadership behaviors and diversity management skills was examined in line with the model proposed by Baron and Kenny (1986). According to this model, in order to test the mediator variable model, there must be a significant relationship between dependent, independent and mediating variables. When the findings in Table 2 were examined, it was seen that all variables had significant relationships among themselves. In addition, if the variable in which the mediation effect is investigated in a significant relationship between variables is added to the model, there is a decrease in the level of the relationship between the variables, this indicates the mediation effect. When the variable that is thought to play a mediating role is added to the model, the relationship between the dependent and independent variable is considered "full mediation"; If the relationship is significant and the effect level decreases, it is considered as "partial mediation."

TABLE 3 | Independent group $t$-test results conducted to determine whether sustainable leadership scale, emotional intelligence scale and diversity management scale scores differ according to teachers' gender variable.

\begin{tabular}{|c|c|c|c|c|c|c|c|c|}
\hline \multirow[t]{2}{*}{ Scale } & \multirow[t]{2}{*}{ Groups } & \multirow[t]{2}{*}{$N$} & \multirow[t]{2}{*}{$\overline{\mathbf{x}}$} & \multirow[t]{2}{*}{ Sd } & \multirow[t]{2}{*}{$\mathrm{Se}$} & \multicolumn{3}{|c|}{$t$-test } \\
\hline & & & & & & $t$ & Df & $p$ \\
\hline \multirow{2}{*}{$\begin{array}{l}\text { Sustainable } \\
\text { leadership }\end{array}$} & Female & 224 & 3.89 & 0.32 & 0.02 & -0.34 & 400 & 0.736 \\
\hline & Male & 178 & 3.90 & 0.32 & 0.02 & & & \\
\hline \multirow{2}{*}{$\begin{array}{l}\text { Emotional } \\
\text { intelligence }\end{array}$} & Female & 224 & 3.92 & 0.33 & 0.02 & -1.60 & 400 & 0.111 \\
\hline & Male & 178 & 3.98 & 0.33 & 0.03 & & & \\
\hline \multirow{2}{*}{$\begin{array}{l}\text { Diversity } \\
\text { management }\end{array}$} & Female & 224 & 3.86 & 0.37 & 0.03 & -0.59 & 400 & 0.559 \\
\hline & Male & 178 & 3.88 & 0.34 & 0.03 & & & \\
\hline
\end{tabular}


TABLE 4 | Results of one-way analysis of variance (ANOVA) conducted to determine whether sustainable leadership scale, emotional intelligence scale and diversity management scale scores differ according to teachers' professional seniority.

\begin{tabular}{|c|c|c|c|c|c|c|c|c|c|c|c|}
\hline Scale & Groups & $n$ & $\overline{\mathbf{x}}$ & Sd & Source of variance & Sum of squares & Df & Mean square & $\boldsymbol{F}$ & $p$ & Dunnet C \\
\hline \multirow[t]{5}{*}{ Sustainable leadership } & $0-5$ years $(1)$ & 115 & 3.84 & 0.35 & Between groups & 0.683 & 4 & 0.171 & 1.708 & 0.147 & \\
\hline & $6-10$ years $(2)$ & 81 & 3.90 & 0.28 & within groups & 39.674 & 397 & 0.100 & & & \\
\hline & $11-15$ years $(3)$ & 82 & 3.90 & 0.32 & total & 40.356 & 361 & & & & \\
\hline & $16-20$ years $(4)$ & 75 & 3.95 & 0.32 & & & & & & & \\
\hline & Total & 49 & 3.93 & 0.27 & & & & & & & \\
\hline \multirow[t]{5}{*}{ Emotional intelligence } & $0-5$ years $(1)$ & 115 & 3.86 & 0.36 & Between groups & 1.247 & 4 & 0.312 & 2.859 & 0.023 & $2-1$ \\
\hline & $6-10$ years $(2)$ & 81 & 3.99 & 0.28 & within groups & 43.284 & 397 & 0.109 & & & \\
\hline & $11-15$ years $(3)$ & 82 & 3.95 & 0.34 & total & 44.530 & 401 & & & & \\
\hline & $16-20$ years $(4)$ & 75 & 4.00 & 0.38 & & & & & & & \\
\hline & Total & 49 & 3.98 & 0.21 & & & & & & & \\
\hline \multirow[t]{5}{*}{ Diversity management } & $0-5$ years $(1)$ & 115 & 3.95 & 0.33 & Between groups & 2.310 & 4 & 0.577 & 4.749 & 0.001 & $2-14-1$ \\
\hline & $6-10$ years $(2)$ & 81 & 3.76 & 0.39 & within groups & 48.266 & 397 & 0.122 & & & \\
\hline & $11-15$ years $(3)$ & 82 & 3.91 & 0.31 & total & 50.576 & 401 & & & & \\
\hline & $16-20$ years $(4)$ & 75 & 3.89 & 0.38 & & & & & & & \\
\hline & Total & 49 & 3.98 & 0.31 & & & & & & & \\
\hline
\end{tabular}

TABLE 5 | Independent group $t$-test results conducted to determine whether sustainable leadership scale, emotional intelligence scale, and diversity management scale scores differ according to the variable of educational status.

\begin{tabular}{|c|c|c|c|c|c|c|c|c|}
\hline \multirow[t]{2}{*}{ Scale } & \multirow[t]{2}{*}{ Groups } & \multirow[t]{2}{*}{$N$} & \multirow[t]{2}{*}{$\overline{\mathbf{x}}$} & \multirow[t]{2}{*}{ Sd } & \multirow[t]{2}{*}{$\mathrm{Se}$} & \multicolumn{3}{|c|}{$t$-test } \\
\hline & & & & & & $t$ & Df & $p$ \\
\hline \multirow[t]{2}{*}{ Sustainable leadership } & Undergraduate degree & 340 & 3.88 & 0.32 & 0.02 & -1.95 & 400 & 0.052 \\
\hline & Graduate degree & 62 & 3.97 & 0.29 & 0.04 & & & \\
\hline \multirow[t]{2}{*}{ Emotional intelligence } & Undergraduate degree & 340 & 3.93 & 0.32 & 0.02 & -2.54 & 400 & 0.012 \\
\hline & Graduate degree & 62 & 4.04 & 0.38 & 0.05 & & & \\
\hline \multirow[t]{2}{*}{ Diversity management } & Undergraduate degree & 340 & 3.85 & 0.34 & 0.02 & -2.43 & 400 & 0.016 \\
\hline & Graduate degree & 62 & 3.97 & 0.40 & 0.05 & & & \\
\hline
\end{tabular}

In this study, it was investigated whether emotional intelligence has a mediating role in the relationship between sustainable leadership (independent variable) and diversity management (dependent variable).

The relationships between sustainable leadership, diversity management and emotional intelligence, which is considered as a mediating variable, were examined by path analysis. The results regarding the mediating effect of emotional intelligence between sustainable leadership and diversity management are shown in Figure 1 and Table 6.

As can be seen in Table 6, sustainable leadership significantly positively predicts emotional intelligence $(\beta=0.68, t=18.76$, $p<0.001)$ and diversity management $(\beta=0.50, t=11.41$, $p<0.000)$. In addition, emotional intelligence significantly positively predicts the diversity management $(\beta=0.83, t=19.57$, $p<0.001)$. Kline (2015) suggested critical values for the evaluation of standardized effect sizes. If it is less than 0.10 , it is low-level impact, if it is around 0.30, it is medium-level impact, and 0.50 and above is high-level impact. Accordingly, it can be said that sustainable leadership and emotional intelligence have a high effect on the diversity management. Sustainable leadership and emotional intelligence together were found to predict $61 \%$ of the variance in diversity management $\left(R^{2}=0.61, p=0.000\right)$. The significance of the regression values between the variables was interpreted as the assumptions of the mediation test were realized. After adding emotional intelligence to the model as a mediator variable, the relationship between sustainable leadership and diversity management was found to be insignificant $(\beta=-0.07, t=-1.74, p>0.05)$. This finding indicates that emotional intelligence plays a full mediating role in the relationship between sustainable leadership and diversity management.

\section{RESULTS AND DISCUSSION}

In this study, sustainable leadership behaviors, diversity management skills and emotional intelligence levels of school principals were examined in line with the views of 402 teachers working in public schools in Pendik and Kartal districts of Istanbul in the 2020-2021 academic year. In addition, the mediating role of emotional intelligence in the relationship between the variables and the relationship between sustainable leadership and diversity management were examined.

Research findings showed that teachers' perceptions of school principals regarding sustainable leadership behaviors are at a high level. In similar research results examining sustainable leadership in educational organizations (Yollu, 2017; Stephens, 2019; 


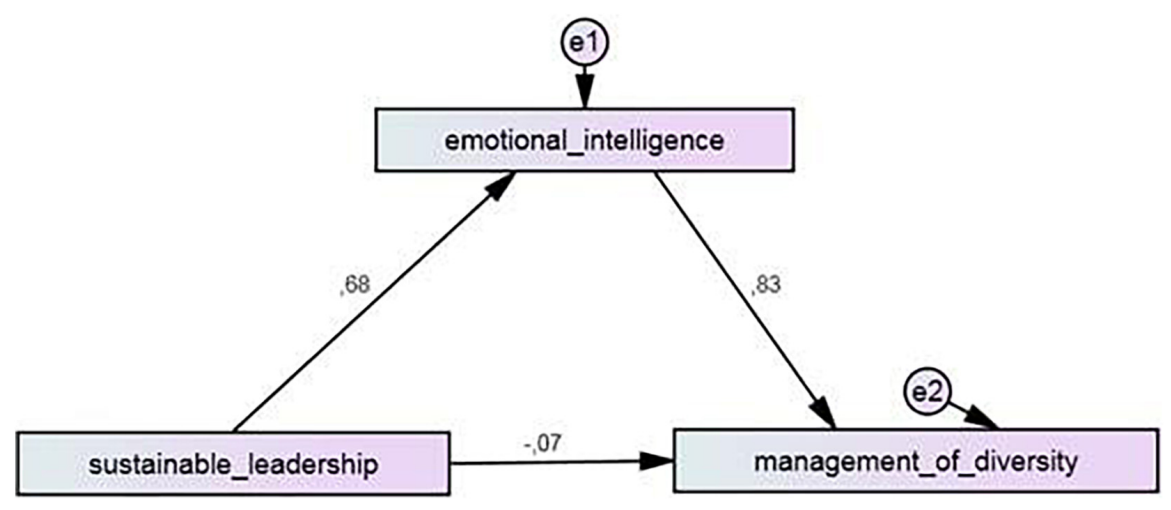

FIGURE 1 | Path analysis diagram for prediction of diversity management (mediation effect).

TABLE 6 | Findings on the mediating effect of emotional intelligence on the relationship between sustainable leadership and diversity management.

\begin{tabular}{llcccc}
\hline Predictor (Exogenous) & Predicted (Endogenous) & $\boldsymbol{B}$ & Se & $\boldsymbol{t}$ & $\boldsymbol{\beta}$ \\
\hline Direct effects & & & & & \\
Sustainable Leadership $\rightarrow$ & Emotional Intelligence & 0.72 & 0.04 & 18.76 & 0.68 \\
Emotional Intelligence $\rightarrow$ & Diversity Management & 0.89 & 0.05 & 19.57 & 0.83 \\
Sustainable Leadership $\rightarrow$ & Diversity Management & 0.55 & 0.05 & 11.41 & 0.50 \\
Indirect effects & & & & -1.74 & -0.00 \\
Sustainable Leadership $\rightarrow$ & Diversity Management & -0.08 & 0.05 & 0.000 \\
\hline
\end{tabular}

Dağdeviren-Ertaş, 2020), it was found that school principals exhibit high levels of sustainable leadership behaviors. In his study, Cook (2014), in which he examined how sustainable school leadership is perceived by teachers, participants stated that sustainable leadership is needed for students to continue their academic development and teachers' professional development, and for this reason, sustainable leadership is important. In this context, it can be considered as a positive situation that school principals exhibit high levels of sustainable leadership behaviors in the findings obtained from both this research and other studies. The development of sustainable characteristics of school leaders is a factor that increases the success of the educational organizations they manage (Lambert, 2012).

Another finding of the study showed that teachers' perceptions of school principals' ability to manage diversity is at a high level. This finding of the study is similar to the results of some studies. E.g., as a result of their researches Memduhoğlu (2007), Young et al. (2010) and Özan and Polat (2013). determined that the perceptions of school principals on the management of diversities are at a high level according to teacher perceptions. However, in their research on educational organizations and Balyer and Gündüz (2010) and determined that teachers' and administrators' perceptions of the management of diversity are moderate. When the literature is examined, it is seen that the perceptions of the education administrators regarding the management of diversity are at a medium and higher level. It is a positive situation that the ability to manage diversities, which is an important point for a leader, is not low. It can be thought that the selection of school principals among senior and successful teachers was effective in achieving such a result. As a matter of fact, it can be thought that the ability to manage diversities can develop with the development of social intelligence of individuals with experience and work and life experience.

The findings showed that teachers' perceptions of school principals regarding their emotional intelligence levels were high. Similar studies on educational organizations (Grobler et al., 2017; Erkoç, 2019) revealed that educators have high emotional intelligence levels. It is of great importance that school administrators, who are teaching leaders, also have emotional intelligence competencies (Recepoğlu, 2012). Because, studies reveal that school principals' emotional intelligence levels are closely related to school success (Bardach, 2008).

Another finding of the study revealed that teachers' perceptions of school principals' sustainable leadership behaviors, diversity management skills and emotional intelligence levels did not differ significantly according to teachers' genders. In their similar studies, Yollu (2017) and Dağdeviren-Ertaş (2020) found that school principals' sustainable leadership behavior levels did not show a significant difference according to the gender variable according to teacher perceptions, while Çayak (2018) found that school principals' sustainable leadership behavior levels were significantly different according to the gender variable of teachers. In this research, the scale scores of male teachers were found to be significantly higher than the scores of female teachers. The issue of gender is one of the basic concepts of diversity management philosophy. Thus; like the glass ceiling theory, one of the biggest obstacles women face in promotions in business life is gender differences. Especially with the increasing participation of women in active business life, companies that aim to turn this into a competitive advantage 
are trying to turn gender differences into wealth rather than a problem (Köksalan, 2019). In this context, it can be considered as a positive situation that teacher perceptions of school principals' skill levels in managing diversity did not show a significant difference according to teachers' genders. When the studies conducted in the context of educational organizations are examined, there are studies that support this finding of the research. E.g., Ekşi et al. (2016) and Küçük (2018) we are revealed that teachers' perceptions of diversity management did not show a significant difference according to the gender variable. However, Balyer and Gündüz (2010) and Kilıçlar-Şahin (2015) revealed in their research that there is a significant difference in favor of male teachers in terms of gender in teachers' perceptions of diversity management. On the other hand, Karademir et al. (2012) revealed that there is a significant difference in favor of female teachers in their research. Therefore, it can be said that the effect of the gender variable on the management of diversity may vary according to different factors such as the organizational structures of the researches or the participants of the research. Turanlı (2007) and Erkoç (2019) in similar studies in which they examined the emotional intelligence levels of school principals also found that there was no significant difference between the opinions of the participants according to the gender variable. This situation supports this finding of the research. However, it is possible to come across studies in the literature showing that there are significant differences between the opinions of the participants according to the gender variable. For example, Güçlü and Recepoğlu (2009) and Recepoğlu (2012) revealed that there are significant differences in favor of female teachers between the opinions of the participants according to the gender variable.

Findings of the study revealed that teachers' perceptions of school principals' sustainable leadership behaviors do not show a significant difference according to teachers' professional seniority; however, it has been revealed that the perceptions of the diversity management skills and emotional intelligence levels show a significant difference according to the professional seniority of the teachers. For emotional intelligence, this difference is in favor of those with 6-10 years of seniority between teachers with 6-10 years of seniority and those with $0-5$ years of seniority. For the diversity management, it is in favor of those with 6-10 years and 16-20 years of seniority between teachers with 6-10 years and 16-20 years of seniority and those with 0-5 years of seniority. In his study, Dağdeviren-Ertaş (2020) found that teachers' perceptions of school principals' sustainable leadership behaviors did not differ significantly according to professional seniority. However, in a similar study, Çayak (2018) revealed that school principals' sustainable leadership behaviors showed a significant difference according to the variable of educational status. In this research, teachers with a seniority of 21 years or more perceive school principals as more sustainable than those with other seniority years.

As in other fields, employees in educational organizations have different demographic, social, cultural, and individual characteristics and it is important to manage them well in line with individual and organizational goals (Memduhoğlu, 2011). In this respect, it can be considered as an expected situation that the perceptions of school principals regarding the ability to manage diversities, as a characteristic of the career stages in which teachers with different professional seniority are in differ. Ekşi et al. (2016) found in a similar study that teachers' perceptions of diversity management differed significantly according to professional seniority. In their similar studies, Yollu (2017) and Dağdeviren-Ertaş (2020) found that school principals' sustainable leadership behavior levels did not show a significant difference according to the gender variable according to teacher perceptions, while Çayak (2018) found that school principals' sustainable leadership behavior levels were significantly different according to the gender variable of teachers., they concluded that as the professional experience of the teachers increased, there was a positive change in the perceptions of the school administration regarding their ability to manage differences. However, unlike the result of this research, Balyer and Gündüz (2010) and Kilıçlar-Şahin (2015) found that the opinions of the participants on the management of diversity did not differ significantly according to professional seniority, as a result of their research in which they examined the perceptions of teachers about the management of diversity in schools. On the other hand, it was seen that different results were obtained in similar studies in which the emotional intelligence levels of the employees in educational organizations were examined according to the variable of professional seniority. In some of these studies, it was observed that the emotional intelligence levels of educators did not differ significantly according to the variable of professional seniority (Erkoç, 2019; Ertuğrul, 2020), while in some of them, it was observed that the levels of emotional intelligence differed significantly according to the variable of professional seniority (Çiçen, 2021).

Findings of the study revealed that teachers' perceptions of school principals' sustainable leadership behaviors, diversity management skills and emotional intelligence levels do not differ significantly according to a teachers' educational status. There are few studies in the literature examining the perceptions of school principals regarding sustainable leadership behaviors according to a teachers' educational status. Of these, Yollu (2017) and Çayak (2018) found that the factors according to the educational status variable in their research; found that school principals' perceptions of sustainable leadership behaviors did not show a significant difference. However, there are studies conducted with different types of leadership using the educational status variable. For example, Değirmenci (2006) and Uygur (2010) found that a teachers' educational background did not cause a significant difference between their perceptions of high school administrators' levels of realizing their cultural leadership roles.

Karademir et al. (2012) and Özan and Polat (2013) who examined the perceptions of teachers regarding the management of diversity in educational organizations, found that teachers' perceptions of diversity management did not show a significant difference according to the variable of educational status. The results obtained from the studies are in line with the results of this study.

Although there are many studies in the literature that show that the emotional intelligence levels of education administrators do not differ significantly according to their education levels and support the result of this research (Acar, 2007; Babaoğlan, 2010), 
it is seen that the employees with high education level are compared to those with low education levels. It is also possible to come across studies showing that individuals have a higher level of emotional intelligence (Canbulat, 2007; Gürbüz and Yüksel, 2008). Therefore, it should not be overlooked that emotional intelligence skills are not the skills learned in the education curriculum, but the skills that the individual gains through his own efforts and experiences.

Another finding of the study is that there are positive and significant relationships between sustainable leadership, diversity management and emotional intelligence. In the literature, no study was found in which all three variables were used together. However, it is frequently emphasized in the literature that organizations should encourage differences rather than ignore them, value the workforce from different backgrounds, and try to improve their ability to manage them, in order to gain a sustainable competitive advantage in differentiated markets (McCann and Kohntopp, 2017; Rahman, 2019; Jankelová et al., 2020). Therefore, when we look at the issue from the point of view of educational organizations, having a strong sustainable leadership structure of the organization for a sustainable success will be the key to the successful management of the diversities within the institution. In addition, studies conducted on both educational organizations and other organizations in the literature reveal that managers' emotional intelligence levels show positive relationships with leadership behaviors (Qian et al., 2017; Boyatzis, 2018; Lone and Lone, 2018). In this respect, these findings obtained from the research are also supported by the literature.

Research findings showed that emotional intelligence has a full mediator role in the effect of school principals' sustainable leadership behaviors on their ability to manage differences. While workforce diversities in schools provide various organizational advantages, they can also lead to some inconveniences. Avoiding these drawbacks depends on seeing the diversities as a wealth and managing them well (Memduhoğlu, 2011). Organization managers have great responsibilities in this regard. Their leadership behaviors are of great importance in the effective management of diversities. However, as the research findings reveal, it is very effective for leaders to understand the individuals in front of them, to empathize with them and to provide a strong organizational communication, in short, to use their emotional intelligence effectively in this process. It is possible to find many studies in the literature that reveal the mediating role of emotional intelligence between similar and different variables (Sarwar et al., 2017; Foster et al., 2018; Yan et al., 2018). In this context, it is important to find emotional intelligence as a mediating variable in this study.

\section{Limitations and Implications for Further Research}

This research has some limitations. The research was conducted in public schools in Istanbul, Turkey's largest city. A similar research can be done with teachers working in rural schools or private schools where fewer teachers work, and the results can be compared. Self-report data collection tools were used to collect the data of the study. Therefore, the data obtained are limited to the answers given by the participants to the measurement tools and the scope of the measurement tools. Considering this limitation, it is thought that it would be beneficial to use different methods such as observation and interview in future studies.

\section{Conclusion and Suggestions}

In the light of the results obtained from this research, some suggestions can be made for researchers and practitioners. Many factors are effective in organizational structures and managerial processes. Therefore, comprehensive researches can be conducted to determine the impact of these factors on the management of diversity, including different types of organizations. The moderator effects of variables such as education level, age, branch, gender, school region can be examined between teachers' perceptions of school administrators' leadership behaviors and their perceptions of the management of diversities. Quantitative research method was used in this study. For this reason, qualitative or mixed research methods can be used in similar studies to have more detailed information about the relationships of the variables.

In addition, some suggestions can be made for practitioners in line with the results obtained from this research. In order to manage diversities in the most effective way, school administrators should adopt a management approach in which all teachers can express their opinions and suggestions clearly, and the diversities of individuals are seen as a wealth. Inservice training can be given to school principals so that they can use their emotional intelligence effectively and efficiently. In addition, qualified sustainable leadership trainings can be provided for school principals to internalize the basic philosophy of sustainability, and thus, sustainable leadership skills of education administrators can be developed at the point of creating a sustainable society.

\section{DATA AVAILABILITY STATEMENT}

The raw data supporting the conclusions of this article will be made available by the authors, without undue reservation.

\section{ETHICS STATEMENT}

The studies involving human participants were reviewed and approved by the Istanbul Medeniyet University Ethics Committee with the decision number 2021/10-02. Only the volunteered participants participated in this study. Written informed consent from the participants' legal guardian/next of kin was not required to participate in this study in accordance with the national legislation and the institutional requirements.

\section{AUTHOR CONTRIBUTIONS}

SÇ devised the research idea, developed the research model, wrote the method part, ran the analytic calculations, limitations, and implications, checked for the literature and discussion part, and 
arranged the last version of the manuscript. ME ran the data collecting process, wrote the introduction part, performed the results, discussion, recommendations, limitations, and controlled

\section{REFERENCES}

Acar, E. (2007). A research on the place and importance of emotional intelligence in business management. Ph.D. thesis. Hatay: Mustafa Kemal University.

Almeida, P., and Chase-Dunn, C. (2018). Globalization and social movements. Annu. Rev. Sociol. 44, 189-211. doi: 10.1146/annurev-soc-073117-041307

Augusty, P. A., and Mathew, J. (2020). Theoretical framework of the relationship between emotional intelligence and effective leadership to ensure sustainability. Int. J. Sci. Technol. Res. 9, 6314-6320.

Avery, G. C., and Bergsteiner, H. (2011). Sustainable leadership practices for enhancing business resilience and performance. Strategy Leadersh. 39, 5-15. doi: $10.1108 / 10878571111128766$

Babaoğlan, E. (2010). Emotional intelligence in school administrators. J. Ahi Evran Univ. Kirsehir Educ. Faculty 11, 119-136.

Badri-Harun, A., Zainol, M. R., Amar, A., and Shaari, Z. H. (2016). Emotional intelligence as mediator between leadership styles and leadership effectiveness: a theoretical framework. Int. Rev. Manage. Mark. 6, 116-121.

Balay, R., and Sağlam, M. (2004). Applicability of diversity management scale in education. Suleyman Demirel Univ. J. Burdur Educ. Faculty 5, 31-46.

Balyer, A., and Gündüz, Y. (2010). Examining the perceptions of administrators and teachers related to diversity management in their schools. Marmara Univ. Atatürk Faculty Educ. J. Educ. Sci. 32, 25-43.

Bardach, R. H. (2008). Leading schools with emotional intelligence: a study of the degree of association between middle school principal emotional intelligence and school success. Ph.D. thesis. Minneapolis: Capella University.

Baron, R. M., and Kenny, D. A. (1986). The moderator-mediator variable distinction in social psychological research: conceptual, strategic, and statistical considerations. J. Pers. Soc. Psychol. 51, 1173-1182. doi: 10.1037/0022-3514.51. 6.1173

Boyatzis, R. E. (2018). The behavioral level of emotional intelligence and its measurement. Front. Psychol. 9:1438. doi10.3389/fpsyg.2018.01438 doi: 10. 3389/fpsyg.2018.01438

Bryan, A. (2010). Corporate multiculturalism, diversity management, and positive interculturalism in Irish schools and society. Ir. Educ. Stud. 29, 253-269. doi: 10.1080/03323315.2010.498566

Büyüköztürk, Ş (2011). Handbook Of Data Analysis For Social Sciences. Ankara: Pegem A Publishing.

Campbell, D. J. (2000). The proactive employee: managing workplace initiative. Acad. Manage. Perspect. 14, 52-66. doi: 10.5465/ame.2000.4468066

Can, A. (2014). Quantitative data analysis in scientific research process with SPSS. Ankara: Pegem A Publishing.

Canbulat, S. (2007). Investigation of the effect of emotional intelligence on employees' job satisfaction. Ph.D. thesis. Ankara: Gazi University.

Çayak, S. (2018). Examining the sustainable leadership behaviors of school principals: a mixed method research. Ph.D. thesis. Istanbul: Marmara University.

Çayak, S., and Çetin, M. (2018). Sustainable leadership scale: validity and reliability study. Turkish Stud. Educ. Sci. 13, 1561-1582. doi: 10.7827/TurkishStudies. 13703

Çiçen, I. Y. (2021). Examining the relationship between teachers' emotional intelligence and psychological capital levels. Ph.D. thesis. Osmaniye: Osmaniye Korkut Ata University.

Clegg, S. R., and Carter, C. (2009). "Globalization and macro-organizational behavior," in The SAGE Handbook of Macro-Organizational Behaviour, eds S. R. Clegg and C. Cooper (London: SAGE), 496-508. doi: 10.1371/journal.pmed. 1001124

Coleman, M. (2012). Leadership and diversity. Educ. Manage. Adm. Leadersh. 40, 592-609. doi: 10.1177/1741143212451174

Cook, J. W. (2014). Sustainable school leadership: the teachers' perspective. Int. J. Educ. Leadersh. Prep. 9, 2-17.

Dağdeviren-Ertaş, B. (2020). Examining the relationship between sustainable leadership and learning organization. Ph.D. thesis. Ankara: Hacettepe University. the other parts in terms of language and contextual check for the manuscript. Both authors contributed to the article and approved the submitted version.
Danilov, I. V., and Mihailova, S. (2020). "Emotions in e-learning: the review promotes advanced curriculum by studying social interaction," in Proceedings of the 6 th International Conference on Lifelong Education and Leadership for $A L L$, (Sakarya: ICLEL).

Davies, B. (2007). Developing sustainable leadership. Thousand Oaks: SAGE Publications.

Değirmenci, S. (2006). The effect of high school administrators' cultural leadership roles on teachers' job satisfaction. Ph.D. thesis. Bolu: Abant Ýzzet Baysal University.

Donaldson-Feilder, E. J., and Bond, F. W. (2004). The relative importance of psychological acceptance and emotional intelligence to workplace wellbeing. Br. J. Guid. Couns. 32, 187-203. doi: 10.1080/0806988041000169 2210

Dulewicz, V., and Higgs, M. (2000). Emotional intelligence- A review and evaluation study. J. Manag. Psychol. 15, 341-372. doi: 10.1108/ 02683940010330993

Ekşi, H., Aksak, M., and Yaman, N. (2016). Investigation of teachers' perceptions on the school administration's ability to manage differences based upon personal meaning profiles and informal relations within organizations. Marmara Univ. Atatürk Faculty Educ. J. Educ. Sci. 44, 33-52. doi: 10.15285/maruaebd.28 6484

Ergin, D. (2008). Teacher Perceptions Of Emotional Intelligence And Transformational Leadership In School Management. Ph.D. thesis. Kocaeli: Kocaeli University.

Erkoç, N. (2019). Examination Of The Relationship Between Primary School Administrators' Resilience, Emotional Intelligence And Managerial Effectiveness Levels. Ph.D. thesis. Malatya: İnönü University

Ertuğrul, N. (2020). The Effect Of Preschool Teachers' Emotional Intelligence Levels On Their Problem Solving Skills. Ph.D. thesis. Istanbul: Istanbul Aydin University.

Foster, B., Lomas, J., Downey, L., and Stough, C. (2018). Does emotional intelligence mediate the relation between mindfulness and anxiety and depression in adolescents? Front. Psychol. 9:2463. doi10.3389/fpsyg.2018.02463 doi: 10.3389/fpsyg.2018.02463

Gardenswartz, L., Cherbosque, J., and Rowe, A. (2010). Emotional intelligence and diversity: a model for differences in the workplace. J. Psychol. Issues Organ. Cult. 1, 74-84. doi: 10.1002/jpoc.20002

Gardner, H. (1983). Frames of Mind Basic Books. New York, NY.

George, D., and Mallery, P. (2003). SPSS for Windows step by step: a simple guide and reference. Boston, MA: Allyn \& Bacon.

Goleman, D. (2016). Emotional Intelligence: why It Is More Important Than IQ and How You Can Improve Yours. Istanbul: Varlık Publications.

Goleman, D. (2017). What Makes a Leader?. Massachusetts: Harvard Business Press.doi: 10.4324/9780429495007-4

Grobler, B., Moloi, C., and Thakhordas, S. (2017). Teachers' perceptions of the utilisation of emotional intelligence by their school principals to manage mandated curriculum change processes. Educ. Manage. Adm. Leadersh. 45, 336-355. doi: 10.1177/1741143215608197

Güçlü, N., and Recepoğlu, E. (2009). The relationship between teacher candidates' emotional intelligence level, leadership styles and their academic success. J. Sakarya Univ. Faculty Educ. 17, 425-442.

Gül, H., İnce, M., and Korkmaz, O. (2014). The mediating role of effective psychological counselor characteristics in the relationship between level of emotional intelligence and counseling self-efficacy. Çă̆ Univ. J. Soc. Sci. 11, 30-49.

Gürbüz, S., and Yüksel, M. (2008). Emotional intelligence in workplace: its relationship with job performance, job satisfaction, organizational citizenship behaviors, and some demographic characteristics. Doğuş Univ. J. 9, 174-190.

Gürdere, C. (2015). Examination of the relationship between the level of emotional intelligence and the styles of coping with stress, anxiety and depression symptoms in university students. Ph.D. thesis. Ankara: Ankara University 
Hargreaves, A. (2007). Sustainable leadership and development in education: creating the future, conserving the past. Eur. J. Educ. 42, 223-233. doi: 10.1111/ j.1465-3435.2007.00294.x

Hargreaves, A., and Fink, D. (2006). Sustainable Leadership. San Francisco, CA: Jossey-Bass.

Iliško, D., and Badyanova, Y. (2014). A case study of ESD implementation: signs of sustainable leadership. Discourse Commun. Sustain. Educ. 5, 38-48. doi: 10.2478/dcse-2014-0004

Ismayllov, Ü (2019). The Effect Of Teachers' Emotional Intelligence On Organizational Trust. Ph.D. thesis. Konya: Necmettin Erbakan University

Jabbour, C. J. C., Gordono, F. S., De Oliveira, J. H. C., Martinez, J. C., and Battistelle, R. A. G. (2011). Diversity management: challenges, benefits, and the role of human resource management in Brazilian organizations. Equal. Divers. Incl. 30, 58-74. doi: 10.1108/0261015111111 0072

Jankelová, N., Joniaková, Z., Procházková, K., and Blštáková, J. (2020). Diversity management as a tool for sustainable development of health care facilities. Sustainability 12, 5226-5248. doi: 10.3390/su1213 5226

Karademir, T., Coban, B., Devecioglu, S., Karakaya, Y. E., and Yücel, A. S. (2012). Views of the teachers and administrators of the high school of fine arts and sports on diversity management. Beden Eğitimi ve Spor Bilimleri Dergisi 6, $62-75$.

Kaufmann, L., and Wagner, C. M. (2017). Affective diversity and emotional intelligence in cross-functional sourcing teams. J. Purch. Supply Manage. 23, 5-16. doi: 10.1016/j.pursup.2016.07.004

Kılıçlar-Şahin, E. (2015). Examining the views of teachers on the management of diversity in primary education institutions. Ph.D. thesis. Ankara: Gazi University

Kline, R. B. (2015). Principles and Practice of Structural Equation Modeling. New York: Guilford Publications.

Köksalan, N. (2019). Management of diversity. Meriç Int. J. Soc. Strateg. Stud. 3, 51-66.

Krejcie, R. V., and Morgan, D. W. (1970). Determining sample size for research activities. Educ. Psychol. Meas. 30, 607-610. doi: 10.1177/001316447003000308

Küçük, M. (2018). Examination Of Teachers' Views On The Management Of Diversity In Imam Hatip Secondary Schools. Ph.D. thesis. Istanbul: Istanbul Sabahattin Zaim University.

Lambert, S. (2011). Sustainable Leadership and the implication for the general further education college sector. J. Furth. High. Educ. 35, 131-148. doi: 10.1080/ 0309877X.2010.540319

Lambert, S. (2012). The implementation of sustainable leadership in general further education colleges. J. Educ. Leadersh. 11, 102-120. doi: 10.12806/v11/i2/rf6

Lone, M. A., and Lone, A. H. (2018). Does emotional intelligence predict leadership effectiveness? An exploration in non-Western context. South Asian J. Hum. Resour. Manage. 5, 28-39. doi: 10.1177/2322093718766806

Lysova, E. I., Allan, B. A., Dik, B. J., Duffy, R. D., and Steger, M. F. (2019). Fostering meaningful work in organizations: a multi-level review and integration. J. Vocat. Behav. 110, 374-389. doi: 10.1016/j.jvb.2018.07.004

McCann, J., and Kohntopp, T. (2017). Developing a sustainable environment for workplace diversity. Int. J. Sustain. Strateg. Manage. 5, 347-365. doi: 10.1504/ IJSSM.2017.089126

Memduhoğlu, H. B. (2007). The management of diversity in public high schools in Turkey according to the opinions of administrators and teachers. Ph.D. thesis. Ankara: Ankara University

Memduhoğlu, H. B. (2011). Organizational consequences of diversity in schools: a case study. Ondokuz Mayıs Univ. Faculty Educ. J. 30, 115-138. doi: 10.7822/ egt40

Morrison, E. W., and Milliken, F. J. (2000). Organizational silence: a barrier to change and development in a pluralistic world. Acad. Manage. Rev. 25, 706-725.

Özan, M. B., and Polat, M. (2013). Perceptions of primary school teachers towards management of diversity (Sample of Muş City). E-Int. J. Educ. Res. 4, 55-77.

Pinder, C. C., and Harlos, K. P. (2001). "Employee silence: quiescence and acquiescence as responses to perceived injustice," in Research in Personnel and Human Resources Management, eds M. Ronald Buckley, J. R. B. Halbesleben, and A. R. Wheeler (Bingley: Emerald Group Publishing Limited), 331-369. doi: 10.1016/s0742-7301(01)20007-3
Pless, N., and Maak, T. (2004). Building an inclusive diversity culture: principles, processes and practice. J. Bus. Ethics 54, 129-147. doi: 10.1007/s10551-0049465-8

Qian, J., Wang, B., Han, Z., and Song, B. (2017). Ethical leadership, leadermember exchange and feedback seeking: a double-moderated mediation model of emotional intelligence and work-unit structure. Front. Psychol. 8:1174. doi: 10.3389/fpsyg.2017.01174

Rahman, U. H. F. B. (2019). Diversity Management and the Role of Leader. Open Econ. 2, 30-39. doi: 10.1515/openec-20190003

Recepoğlu, E. (2012). An investigation of school principals' levels of emotional intelligence according to the teachers' perceptions in terms of different variables. Milli Eğitim Dergisi 41, 149-165.

Salovey, P., and Mayer, J. D. (1990). Emotional intelligence. Imagin. Cogn. Pers. 9, 185-211. doi10.2190/DUGG-P24E-52WK-6CDG

Sarwar, H., Nadeem, K., and Aftab, J. (2017). The impact of psychological capital on project success mediating role of emotional intelligence in construction organizations of Pakistan. J. Glob. Entrep. Res. 7, 1-13. doi: 10.1186/s40497017-0080-4

Shen, J., Chanda, A., D’netto, B., and Monga, M. (2009). Managing diversity through human resource management: an international perspective and conceptual framework. Int. J. Hum. Resour. Manage. 20, 235-251. doi: 10.1080/ 09585190802670516

Stephens, A. J. (2019). Principals' Sustainable Leadership Behaviors and Their Impact on the International Baccalaureate Primary Years Programme in Urban Schools. Ph.D. thesis. College Station, Texas, United States: Texas A\&M University

Suriyankietkaew, S., and Avery, C. G. (2014). Employee satisfaction and sustainable leadership practices in Thai SMEs. J. Glob. Responsib. 5, 160-173. doi: 10.1108/ jgr-02-2014-0003

Suriyankietkaew, S., and Avery, G. (2016). Sustainable leadership practices driving financial performance: empirical evidence from Thai SMEs. Sustainability 8:327. doi: 10.3390/su8040327

Teece, D. J. (2018). Dynamic capabilities as (workable) management systems theory. J. Manage. Organ. 24, 359-368. doi: 10.1017/jmo.20 17.75

Titrek, O. (2005). Developing the scale of the level of using the competence of emotional intelligence in profession life: validity and reliability studies. Turkish Psychol. Couns. Guid. J. 3, 73-87.

Titrek, O. (2013). Iq'dan Eq'ya Duyguları Zekice Yönetme. İstanbul: Pegem Publishing.

Trittin, H., and Schoeneborn, D. (2017). Diversity as polyphony: reconceptualizing diversity management from a communication-centered perspective. J. Bus. Ethics 144, 305-322. doi: 10.1007/s10551-015-2825-8

Turanl, A. (2007). Emotional intelligence of primary school principals and job satisfaction levels of teachers. Ph.D. thesis. İzmir: Dokuz Eylul University

Ulrich, D., and Smallwood, N. (2013). Leadership Sustainability: seven Disciplines to Achieve the Changes Great Leaders Know They Must Make. Boston: McGrawHill. doi: 10.1002/ltl.20098

Urbancová, H., Čermáková, H., and Vostrovská, H. (2016). Diversity management in the workplace. Acta Univ. Agric. et Silvic. Mendelianae Brun. 64, 1083-1092. doi: 10.11118/actaun201664031083

Urbancová, H., Hudáková, M., and Fajčíková, A. (2020). Diversity management as a tool of sustainability of competitive advantage. Sustainability 12:5020. doi: $10.3390 /$ su12125020

Uygur, M. (2010). The Relationship Between Primary School Administrators' Levels Of Realizing Their Cultural Leadership Roles And Teachers' Organizational Commitment. Ph.D. thesis. Konya: Selcuk University

Weisinger, H. (1998). Emotional Intelligence at Work. Trans: nurettin Süleymangil. İstanbul: MNS Publishing.

Yahyayeva, A. Y. (2020). "The role of investment in ensuring sustainable business development," in Proceedings of the 6 th International Conference on Lifelong Education and Leadership for ALL, (Sakarya: ICLEL).

Yan, X., Yang, K., Su, J., Luo, Z., and Wen, Z. (2018). Mediating role of emotional intelligence on the associations between core self-evaluations and job satisfaction, work engagement as indices of work-related well-being. Curr. Psychol. 37, 552-558. doi: 10.1007/s12144-016-9531-2 
Yollu, S. (2017). Application Levels Of School Principals' Sustainable Leadership Strategies. Ph.D. thesis. Ankara: Ankara University

Young, B. L., Madsen, J., and Young, M. A. (2010). Implementing diversity plans: principals' perception of their ability to address diversity in their schools. NASSP Bull. 94, 135-157. doi: 10.1177/0192636510379901

Zeltina, M. (2020). "Design thinking for sustainable development," in Proceedings of the 6 th International Conference on Lifelong Education and Leadership for $A L L$, (Sakarya: ICLEL).

Conflict of Interest: The authors declare that the research was conducted in the absence of any commercial or financial relationships that could be construed as a potential conflict of interest.
Publisher's Note: All claims expressed in this article are solely those of the authors and do not necessarily represent those of their affiliated organizations, or those of the publisher, the editors and the reviewers. Any product that may be evaluated in this article, or claim that may be made by its manufacturer, is not guaranteed or endorsed by the publisher.

Copyright () 2021 Çayak and Eskici. This is an open-access article distributed under the terms of the Creative Commons Attribution License (CC BY). The use, distribution or reproduction in other forums is permitted, provided the original author(s) and the copyright owner(s) are credited and that the original publication in this journal is cited, in accordance with accepted academic practice. No use, distribution or reproduction is permitted which does not comply with these terms. 